\title{
Inspiracje kulturami lokalnymi w awangardowej architekturze początków XXI w.
}

\section{Local cultural inspirations in avant-garde architecture in the wake of the twenty-first}

\section{century}

\begin{abstract}
Streszczenie
Tematem artykułu jest próba stworzenia systematyki dotyczącej sposobów wykorzystania motywów regionalnych w awangardowej architekturze pierwszych dwóch dziesięcioleci XXI w. Wykorzystanie lokalnych wzorców związane było z tworzeniem architektury od jej początków. Architektura ponowoczesna zakwestionował idee uniwersalizmu, a pośród różnych jej nurtów ważną rolę odgrywała architektura regionalna. W początkach XXI w. w architekturze awangardowej doszło do kolejnego przewartościowania sposobów wykorzystania lokalnych inspiracji. W artykule podjęto próbę dokonania systematyki współczesnych rozwiązań, wyróżniając trzy podstawowe kategorie: a) inspiracje formą architektoniczną, b) inspiracje materiałem budowlanym i rzemiosłem, c) inspiracje „ideą wspólnotową". Omówiono wybrane, reprezentatywne przykłady współczesnych rozwiązań, podkreślając ich specyfikę na tle wcześniejszych realizacji.
\end{abstract}

\section{Summary}

This paper attempts to systematise the manner in which avant-garde architecture employed regional motifs during the first two decades of the twenty-first century. Architecture has used local patterns since its beginnings. However, as soon as the models of architectural orders had become widespread in the modern era, folk architecture and inspirations drawn from regional traditions were marginalised. Post-modern architecture questioned the ideas of universal practices, giving prominence to regional architecture. At the beginning of the twenty-first century, avant-garde architecture once more redefined the employment of local traditions as inspirations. The paper seeks to systematise the modern references to local traditions, distinguishing three basic categories: a) inspirations by architectural form, b) inspirations by construction materials and craft, c) inspirations by the 'idea of community'. The selected examples are representative of these modern architectural solutions, and are discussed in connection to earlier projects.

Słowa kluczowe: Architektura regionalna, styl narodowy, materiały budowlane, rzemiosło Keywords: Regional architecture, national style, building materials, craft

\section{Wstęp}

Inspiracje architekturą i kulturą regionalną stanowią jedną z najważniejszych dróg rozwoju awangardowej architektury początków XXI w. Formę jaką przybrały w tym obszarze współczesne poszukiwania, oceniać należy w dłuższej perspektywie historycznej. Choć znaczna część rozwoju architektury nowoczesnej oparta była o idee uniwersalistyczne, to równolegle przebiegały także procesy inspirowania się rozwiązaniami lokalnymi. W początkach $X X I$ w. architektoniczny regionalizm przybrał nową postać, która nawiązując do poprzednich dokonań, posiada jednak oryginalny charakter. Podstaw oryginalności architektury współczesnej inspirowanej kulturą lokalną, należy według autora poszukiwać w czterech podstawowych źródłach:

\section{Introduction}

Inspirations drawn from regional culture and architecture significantly contributed to the development of avant-garde architecture at the beginning of the 21 st century. The form of the contemporary explorations in this respect should be assessed from the further-reaching historical perspective. Even though the development of architecture largely rested on the concept of universalism, parallel processes were inspired by local traditions. At the beginning of the 21st century, architectural regionalism took on a new form, which was original albeit influenced by earlier models. The main sources of originality of contemporary architecture inspired by local culture are as follows: 


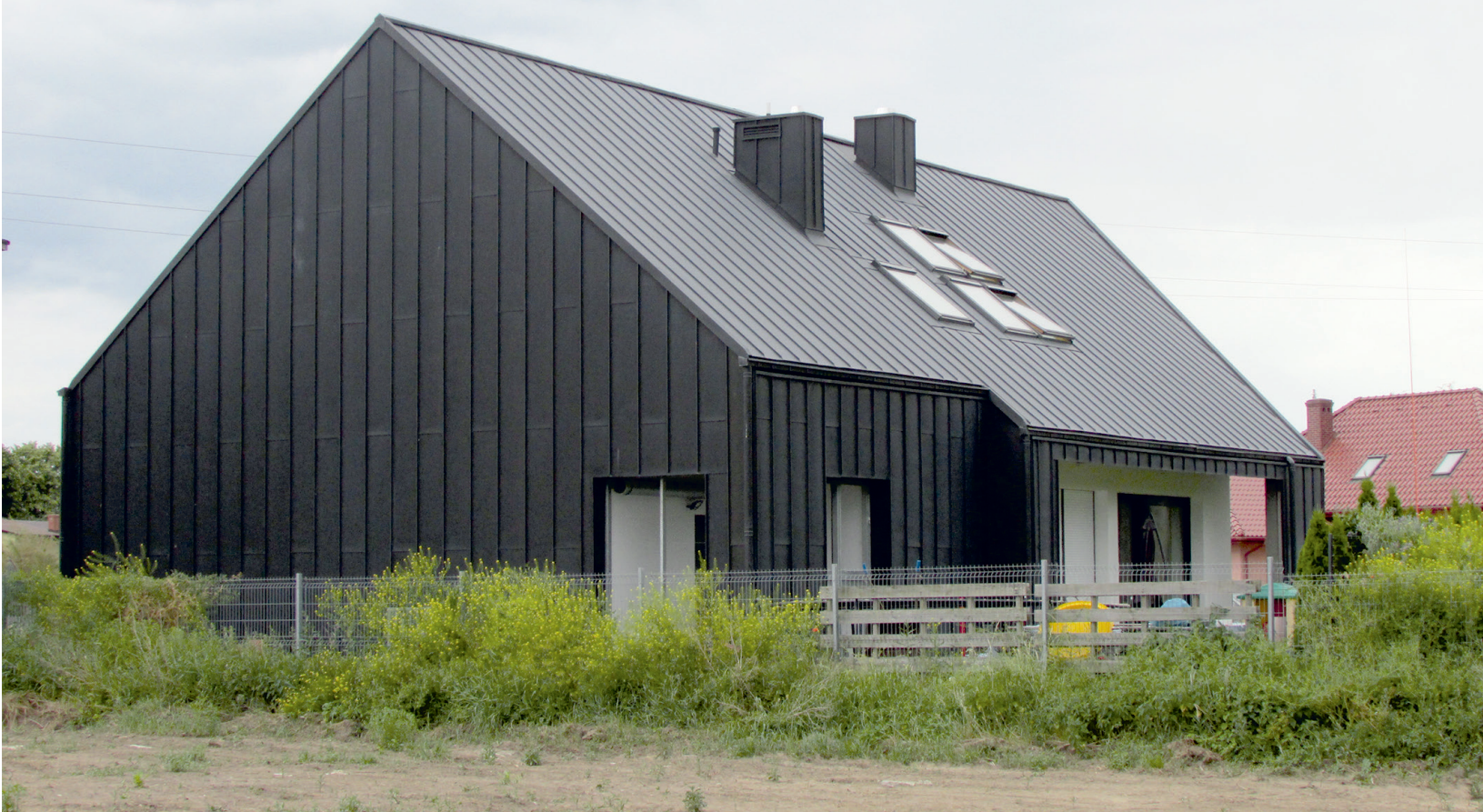

II. 1. Zabudowa jednorodzinna w gminie Dobra Szczecińska, stanowiącej cześć aglomeracji szczecińskiej. Forma nawiązująca do archetypu "domu-stodoły". Przykład formy inspirowanej architekturą lokalną, która w XXI w. uzyskała zasięg globalny. Parterowe budynki z wysokimi dachami projektowane są na terenach podmiejskich na różnych kontynentach, a ich twórcy odwołują się najczęściej do tradycyjnych korzeni lokalnej architektury. (Źródło: fotografia autora)

III. 1. Example of detached housing in the municipality of Dobra Szczecińska from the agglomeration of Szczecin. Its architectural form evokes the archetypical model of the so-called 'barn house'. Architecture inspired by regional forms, which this instance exemplifies, went global at the beginning of the twenty-first century. One-storey buildings with high ridge roofing occur particularly in the suburban areas of various countries, and their designers usually refer to traditional architecture with local roots. (Source: photo by the author)

- w zglobalizowanym świecie architektury regionalizm stał się atutem, który pozwala na wyrażenie odrębności i indywidualizmu;

- nastąpił rozwój technologii budowlanych, przy równoczesnym renesans tradycyjnymi rozwiązaniami budowlanymi;

- nastąpił rozwój technik informacyjnych, co wpłynęło na zwiększenie przepływu informacji i rozwiązań projektowych w perspektywie globalnej;

- nastąpiło przedefiniowanie obszaru inspiracji, który został poszerzony o szeroko rozumiany kontekst kulturowy, a nawet próby wyrażania poprzez architekturę, pozornie abstrakcyjnych idei charakterystycznych dla danej wspólnoty.

Wartym podkreślenia jest zacieranie się obowiązującej przez stulecia antynomii pomiędzy "architekturą wysoką", związanej najczęściej z formami porządkowymi, i „architekturą ludową". Szczególnie w konsekwencji masowości dostępu do informacji, obserwować można zjawisko, w którym projekty powstające w konkretnym kontekście kulturowym bywają naśladowane przez twórców w innych częściach świata. Tworzy to sytuację, w której to w architekturze początków XXI w. można mówić o modzie na "globalny regionalizm" (il. 1.).

Tematem artykułu jest próba systematyki współczesnych postaw twórczych, odwołujących się do regionalizmu w projektowaniu architektonicznym w perspektywie historycznej. Przyjęto metodę badawczą polegająca na analizie wybranych, reprezentatywnych przykładów. Badania podzielono na trzy części. W pierwszej części dokonano analizy historycznej, przedstawiającej główne nurty wykorzystujące inspiracje lokalne w architekturze
- In the globalized world of architecture, regional inspirations have become an asset which facilitates the expression of individuality and uniqueness.

- The development of engineering technologies occurred simultaneously with the renaissance of traditional construction practices.

- The development of communication technologies triggered an increase in information exchange which helped to popularize certain engineering practices on a global scale.

- Architectural inspirations were broadened by a wide cultural context which included attempts to express abstract ideas characteristic of a certain community by architectural means.

It is worth noting that the long-standing antinomy between elite architecture frequently informed by classical forms and 'folk architecture' has gradually vanished. This resulted from an open access to information and was manifested in the imitations of projects derived from specific cultural contexts in other parts of the world unrelated to these contexts. The fashion for these practices is often referred to as 'global regionalism' (ill. 1.).

This article attempts to systematize the approaches of contemporary architects to the concept of regional traditions seen from a historical perspective. The adopted research method is based on the analysis of selected representative examples. The study is divided into three parts. In the first part, a historical analysis has been conducted, highlighting the main approaches to local inspirations in contemporane- 
współczesnej od końca XIX do końca XX w. Część druga to systematyka rozwiązań powstałych na początku XXI w., wraz z próbą ich syntetycznego podsumowania. W zakresie badań ujęto wybrane, reprezentatywne przykłady rozwiązań architektonicznych, których powstanie inspirowane było kulturą regionalna. Część trzecia to podsumowanie przeprowadzonych badań.

\section{Regionalizm w głównych nurtach architektury współ- czesnej od końca XIX w. do końca XX w., w kontekście wpływu na współczesne postawy twórcze.}

Architektura nowoczesna od końca XIX w. do końca XX w. pozostawała w głównej mierze pod wpływami tendencji uniwersalnych. Jednak w kilku momentach historycznych architektoniczna awangarda odnosiła się do kultur lokalnych. Najczęściej odwołania te miały charakter ideowy i były próbą tworzenia alternatywy wobec głównych nurtów rozwojowych. Pozwala to ze współczesnej pespektywy według autora wyróżnić cztery nurty historyczne, które pośrednio znajdują odbicie we współczesnej twórczości architektonicznej:

- „neohistoryczne style narodowe";

"fascynacji architekturą swojską";

- regionalizmu w architekturze modernizmu;

- postmodernistycznej restytucji regionalizmu.

a) "Style narodowe”.

Poszukiwania "stylów narodowych" pojawiły się w drugiej połowie XIX w. i były kontynuowane $w$ XX w. W drugiej połowie XIX w. obserwować można było próby tworzenie stylów, które zgodnie z założeniami ich twórców, poprzez swoją specyfikę formalną, wyrażać miały rozwiązania "typowe dla danego narodu". Pod względem formalnym były to najczęściej próby przeciwstawienia się tradycji klasycznego eklektyzmu, którą utożsamiano z uniwersalizmem i nawiązania do tradycji architektury średniowiecznej.

Poszukiwania te postrzegać należy w szerszej perspektywie kulturowej, jako wyraz rodzenia się i umacniania tożsamości narodowych, w których to architektura odgrywać miała istotną rolę. Interesujące i reprezentatywne były w tym względzie poszukiwania architektury polskiej. Pomimo braku istnienia polskiej państwowości, architekci na ziemiach polskich podjęli się prób tworzenia lokalnych stylów, które odwoływały się do historii polskiej architektury. W odniesieniu do architektury sakralnej tego okresu Krzysztof Stefański wyróżnił trzy podstawowe style, nawiązujące do architektury gotycko-romańskiej: "styl wiślano-bałtycki”, „styl przejściowy" i "styl nadwiślański” (Stefański, 2002, s. 29). Jak pisał entuzjasta neogotyku Karol Matuszyński: "Styl ten, odpowiadający warunkom klimatycznym Polski, upodobaniom i uczuciom religijnym narodu, szybko zrósł się z polską ziemią i stał się w zupełności stylem swojskim (Matuszewski, 1880, s. 370)". Poszukiwania w nurcie "stylów narodowych" kontynuowane były w okresie międzywojennym, przybierając w przypadku architektury polskiej postać wręcz promowaną przez państwo. Okres ten stał się momentem instytucjonalizowanego triumfu idei narodowych, ale i jego zmierzchem. ous architecture between the end of the 19th century and the end of the 20th century. The second part systematizes and recapitulates the analogous realizations implemented at the beginning of the 21 st century on the basis of selected representative examples of architectural solutions inspired by regional culture. The third part summarizes the conducted research.

Regional traditions in contemporary architecture between the end of the 19th and the end of the 20th century and their influence on the main strategies in architectural design

Between the end of the 19th century and the end of the 20th century, contemporaneous architecture was generally influenced by the universal movement. However, in some cases avant-garde architecture drew inspiration from local cultures. These references were predominantly ideological and aimed at providing an alternative to mainstream developments. They can be divided into four historical tendencies which directly influenced the contemporary architectural design:

- 'Neo-historical national style'

- Interest in 'homey architecture'

- Regional traditions in modernist architecture

- Postmodern revival of regional traditions.

\section{a) 'National style'}

The search for 'national style' emerged in the second half of the 19th century and was continued in the 20th century. In the second half of the 19th century, attempts were undertaken to create styles which, according to their creators, expressed formal features 'typical for a specific nation'. In terms of formal features, they usually opposed the principles of traditional classical eclecticism which was associated with a universal design and references to medieval traditions.

This search can be perceived in a broader cultural perspective as the beginnings of the concept of national identity in which architecture was to play an important role. In this respect, Polish explorations of a national style were representative and interesting. Despite the lack of Polish statehood, architects from the former Polish territory attempted to recreate local styles, looking back at models from Polish history. With regard to sacred architecture of this period, Krzysztof Stefański distinguished three basic styles drawing on Romanesque and Gothic architecture: 'Vistula Baltic' style, 'transitional' style, and 'Vistula' style (Stefański, 2002, p. 29). Karol Matuszyński, a great enthusiast of Gothic Revival, wrote: "this style corresponding to Polish climate conditions, as well as Polish ideals and religious beliefs, was soon adopted in the Polish land and became a domestic style" (Matuszewski, 1880, p. 370). The development of 'national styles' continued in the Interwar period, winning the support of the Polish state. This period saw at the same time the institutionalized triumph of national styles and their downfall. From the modern-day perspective, the idea of 'national styles', especially in terms of references to Gothic and Romanesque formal features, is already 
Ze współczesnej perspektywy idee „stylów narodowych", szczególnie w postaci odniesień do formalistyki gotycko-romańskiej, uznać należy za zamknięty rozdział w historii architektury. Poszukiwania te charakterystyczne były dla określonego momentu historycznego, wpisującą architekturę w procesy rodzenia się tożsamości narodowych. Znaczenie tego okresu polega jednak na wykreowaniu zjawiska poszukiwania „stylu narodowego", który w dłuższej perspektywie przekształcił się w kolejne fazy poszukiwań regionalnych.

\section{b) „Architektura swojska”}

Także na przełomie XIX i XX w. w sztuce europejskiej doszły do głosu kierunki odwołujące się do motywów ludowych i lokalnego rzemiosłem. Przed narodzinami modernizmu inspirowanego "estetyką maszyny", szczególnie w pierwszym dziesięcioleciu XX w., w architekturze widoczne stały się inspiracje architekturą wsi i twórczością ludową. Inspiracje te łączono z lokalnym rzemiosłem i materiałami, szczególnie z wykorzystaniem drewna, jako tradycyjnego materiału konstrukcyjnego i zdobniczego. Idee rzemiosła sprzeciwiającego się produkcji masowej zapoczątkowane zostały przez ruch Arts and Crafts Movement (początki lata 60. XIX w.). Przełomowym momentem odniesień do kultury wsi okazała się opublikowana przez Ebenezer Howard książka Garden Cities of To-Morrow (1902), stając się początkiem nowego ruchu w urbanistyce i architekturze. Lokalne odmiany idei miasta-ogrodu pojawiły się w różnych krajach europejskich, a na szczególne wyróżnienie zasługuje wkład Hermanna Muthesiusa. Ten teoretyk i praktyk architektury, promował nowoczesną architekturę, łączącą ówczesne osiągniecia techniczne z architekturą i krajobrazem wsi. Idee te stały się inspiracjami dla wielu ówczesnych europejskich architektów, urbanistów, samorządowców i inwestorów, którzy łączyli je często także z formami narodowymi.

Także i w tym zakresie architektura polska uznana może być za reprezentatywną dla całego nurtu. Początki odniesień do kultury regionalnej poszukiwać należy już w oryginalnej twórczości Stanisława Witkiewicza i w „stylu zakopiańskim”. Według Stefańskiego w latach 1906-1914 w architekturze polskiej wykrystalizował się "styl swojski”, wywodzący się w głównej mierze z architektury dawnych drewnianych kościołów wiejskich (Stefański K., 2002, s. 107). Styl ten w stosunku do wcześniejszych projektów w duchu gotycko-romańskim uznać należy za znacznie bardziej swobodny i silniej związany z lokalną tradycją. Stosunkowo szybko w architekturze polskiej zauważyć można także odniesienia do idei miasta-ogrodu, które znalazły swą materializację m.in. w formie nawiązań do dworu polskiego.

"Idee swojskości" pozostały aktualne także we współczesnej architekturze światowej i polskiej. Motywy te nabrały jednak w początkach XXI w. odmiennego charakteru, odwołującego się często do estetyki minimalizmu, czy też wykorzystujące cyfrowe transformacje. Równocześnie poza awangardą także w „architekturze masowej", szczególnie na obszarach podmiejskich, rozwiązania te pozostają wciąż aktualne. O żywotności tych tradycji w architekturze polskiej świadczyć może m.in. trwająca od ponad stu lat popularność odniesień do „stylu zakopiańskiego", czy też "architektury dworkowej”. a closed chapter in the history of architecture. The search for national styles was characteristic of a certain moment in history, related to the processes of national identity development, and gave birth to further explorations of regional character.

\section{b) 'Homey architecture'}

In the wake of the 20th century, movements inspired by folk motifs and crafts gained prominence in the European architecture. Before the onset of modernism informed by the so-called 'machine esthetics', inspirations drawn from rural architecture and folk art became especially widespread in the first decade of the 20th century. These inspirations were particularly related to regional crafts and materials, especially wood, which was used as a traditional construction and ornamentation component.

The concept of crafts opposed to mass production gave rise to the Arts and Crafts Movement at the beginning of 1860s. A turning point in the history of references to rural culture was a book published by Ebenezer Howard entitled Garden Cities of To-Morrow (1902), which marked the beginning of a new movement in urban planning and architecture. Afterwards, local varieties of the idea of garden city emerged in various European towns. In this respect, the contribution of Hermann Muthesius deserves a special mention: this theoretician and practitioner of architecture promoted the idea of contemporary architecture linking contemporaneous technical acquisitions with rural landscapes and architecture. His views inspired many European architects, urbanists, local government authorities and investors, who associated them with forms derived from national traditions.

Polish architecture exhibiting the features mentioned above was representative of the entire movement. References to Polish regional culture started with the creation of 'Zakopane Style' by Stanislaw Witkiewicz, a Polish painter, art theoretician, and amateur architect. According to Stefański, the 'homey style' developed in Polish architecture on the basis of old wooden rural churches was established between 1906-1914 (Stefański K., 2002, p. 107). Compared to earlier designs inspired by Gothic and Romanesque buildings, this style was less restrictive and strongly drawing on local tradition. Additionally, the references to the concept of Garden City soon permeated Polish architecture, usually taking the form of references to Polish manor house.

The concept of 'homey style' lingered in both Polish and world architecture, even though its character was transfigured through parallels with minimal art aesthetics as well as digital transformations at the beginning of the 21 st century. Simultaneously, apart from avant-garde architecture, its influences are still visible in the mainstream designs implemented particularly in suburban areas. The endurance of these traditions in Polish architecture is evidenced by the unwaning popularity of motifs derived from the ' $\mathrm{Za}$ kopane Style' and 'Manor House' architecture. 
c) Regionalizm w architekturze modernizmu.

Termin „międzynarodowy" w odniesieniu do architektury modernistycznej po raz pierwszy użyty został przez Waltera Gropiusa w 1925 r. w publikacji „Internationale Architektur" (Fauria G., Evers B., Thoenes Ch., 2003, s. 722). Pojęcie "styl międzynarodowy" („international sty$\left(e^{\prime \prime}\right)$ związane jest z wystawą "The International Style: Architecture since 1922" (Fauria G., Evers B., Thoenes Ch., 2003, s. 714), która została zaprezentowana w Musem of Modern Art w Nowym Jorku w 1932 r. Architektura modernistyczna, szczególnie w swych początkach i okresie międzywojennym, oparta była na poszukiwaniach rozwiązań uniwersalnych, ideowo wykluczających formy regionalne. Pomimo tych pryncypialnych założeń, także i w architekturze modernistycznej zauważyć można wpływy inspiracji lokalnych, które nasiliły się zwłaszcza w późnym modernizmie. Jako wymowne przykłady tych poszukiwań podać można m.in. rozwiązania architektury fińskiej ${ }^{1}$, brazylijskiej ${ }^{2}$, czy też japońskiej ${ }^{3}$. Każdy z tych kierunków w twórczy i odmienny sposób odnosił się do tradycji, czy też zastosowania lokalnych materiałów, reinterpretując je najczęściej w abstrakcyjnych formach. Także w polskiej architekturze modernistycznej powstałej po II wojnie światowej odnaleźć można wręcz wybitne przykłady regionalnych odniesień ${ }^{4}$.

Modernistyczne odwołania do tradycji, a szczególnie ich abstrakcyjny wymiar, pozostaje wciąż aktualny, szczególnie w tradycji architektów nowego modernizmu. W stosunku do późnego modernizmu charakteryzuje się on większą dyscypliną formalną i częstym wykorzystaniem estetyki minimalistycznej. Wpłynęło to na sposób przetwarzania inspiracji. O ile bowiem w późnym modernizmie były to najczęściej formy rzeźbiarskie, to obecnie nawiązania te są znacznie bardziej subtelne, poprzestające często jedynie na przetworzonym detalu architektonicznym.

d) Postmodernistyczna restytucja regionalizmu.

Architektura postmodernistyczna posiadała różne nurty stylistyczne. Zerwanie z modernistyczną i abstrakcyjną tradycją otwierało teoretyków i architektów nowego nurtu na szeroki wachlarz historycznych inspiracji. Z dzisiejszej perspektywy, wydaje się, że kluczowe okazały się dwie postawy odwołujące się ideowo do tradycji architektury: tradycjonalizm i „krytyczny regionalizm”. Tradycjonalizm czerpał przede wszystkim z inspiracji formami architektury klasycznej, którą starał się implementować w postmodernistycznym projektowaniu. Propagatorzy tego nurtu podkreślali konieczność zachowania ciągłości kulturowej w sposobie budowy formy architektonicznej, która została według nich zakłócona przez abstrakcyjny modernizm. W 1977 r. krytyk architektury David Watkin pisał: "Tymczasem zgodnie z dawnymi przekonaniami ludzka natura nie zmienia się z pokolenia na pokolenia. Co więcej, artyści kontynuują tradycje, które mogą być interpretowane i rozwijane przez innych artystów. Dzięki temu możliwe jest przetrwanie i rozwój tradycji kulturowych (...)" (Jencks, Kropf, 2013, s. 204). W 1986 r. dwaj historycy i teoretycy architektury Alexander Tonis i Liane Lefaivre, analizując sposoby wykorzystania motywów klasycznych w architekturze lat 80 . XX w. stworzyli c) Regional traditions in modernist architecture

The term 'international' was first used by Walter Gropius with regard to modernist architecture in 1925 in his publication Internationale Architektur (Fauria G., Evers B., Thoenes Ch., 2003, p. 722), while the term 'international style' is connected to the exhibition The International Style: Architecture since 1922 (Fauria G., Evers B., Thoenes Ch., 2003, p. 714) presented by the Museum of Modern Art in New York in 1932. Modernist architecture, especially in its initial phase in the Interwar period, sought to develop universal design solutions, ideologically independent from regional forms. However, despite these principles, it was continuously pervaded by inspirations with local traditions which proliferated in the late modernism. The most representative examples of these inspirations may be found in the Finnish, ${ }^{1}$ Brazilian $^{2}$ and Japanese ${ }^{3}$ architecture. Each of these movements evoked tradition in a distinct and creative manner-for instance, by means of the use of local materials-usually reinterpreting it in abstract forms. Polish modernist architecture of the Postwar period also holds many outstanding instances of references to regional traditions. ${ }^{4}$

Modernist inspirations with traditional forms, and especially their abstract dimension, have persisted particularly among designs of the neomodern movement. In comparison to late modernism, it exhibits a greater formal discipline and frequent employment of minimal art aesthetics. This had a significant influence on the form of inspirations. While late modernism preferred sculpted forms, the influences have become more subtle, often restricted to forms of architectural details in the neomodern movement.

\section{d) Postmodern revival of regional traditions}

Postmodern architecture comprised diverse stylistic movements. The rejection of modernist and abstract practices paved the way towards a wide range of historical inspirations. Two ideological approaches to architectural traditions emerged as especially crucial from the modern-day perspective: traditionalism and the so-called 'critical regionalism'. The former was mainly inspired by forms derived from classical architecture, trying to apply them to postmodern design. Propagators of this movement emphasized the need to maintain a cultural continuity of architectural forms, which, according to them, had been distorted by abstract modernism. In 1977, David Watkin, an architectural historian, wrote: "But according to an older belief, human nature does not alter from generation to generation. Moreover, artists develop traditions which are capable of interpretation and development by other artists. It is these facts which make possible the survival and development of tradition in a culture (...)" (Jencks, Kropf, 2013, p. 204). In 1986, Alexander Tzonis and Liane Lefaivre, two historians and theoreticians of architecture, having analyzed the manner of application of classical motifs in the architecture of the 1980s, created the term of 'critical re- 
pojęcie "krytycznego regionalizmu". Miał być on alternatywą wobec uniwersalnego modernizmu, a twórcy pojęcia stworzyli następującą systematykę odniesień dla tradycyjnej architektury: "Zaryzykujemy stwierdzenie (...), że są trzy główne sposoby wybiórczego stosowania klasycznego kanonu: 1. "cytatyzm" klasycznych motywów, albo tak zwany swobodny klasycyzm, 2. synkretyzm, 3. zastosowanie klasycznych fragmentów $w$ architektonicznym metakomunikacie" (Jencks, Kropf, 2013, s. 219). W kolejnych latach pojęcie „krytycznego regionalizmu" zostało twórczo rozwinięte przez lokalnych architektów na całym świecie i coraz bardziej odeszło od tradycji klasycznej, przesuwając się w strony większego udziału form lokalnych.

Ze współczesnej perspektywy pojawienie się teorii postmodernizmu w projektowaniu architektonicznym stało się początkiem restytucji tradycjonalizmu. Wciąż widoczne są w nim dwa podstawowe nurty: odwołania do tradycji klasycznej, która obecnie najpełniej reprezentuje idee „nowego urbanizmu” głoszone przez Leona Kriera i Księcia Walii Karola, oraz "krytycznego regionalizmu”, który systematycznie poszerzał wachlarz swoich formalnych odniesień o architekturę spoza tradycji klasycznej.

\section{Inspiracje kulturą lokalną w awangardowej architektu- rze początków XXI w.}

Próbując nakreślić syntetyczny obraz architektury pierwszych dwóch dziesięcioleci XXI w., który uwzględniałby inspiracje kulturą lokalną, należy podkreślić wielowątkowość współczesnych poszukiwań. „Regionalizm” stał się modą, wykorzystywaną w różnych konwencjach architektonicznych i w różny sposób odwołujący się do tradycji. Tworzy to szeroką panoramę przykładów, które różnią się od siebie wręcz biegunowo. Część z nich bazuje na genezie tradycyjnej architektury, oryginalnych materiałach, technologiach i formach, próbując je implementować w dosłowny sposób we współczesnych rozwiązaniach. Równocześnie wciąż obecne są rozwiązania powierzchowne, traktujące formy tradycyjne jak rodzaj detalu, bez powiązań ze strukturą i formą budynku. Należy także podkreślić wielość tradycji, z których czerpią współcześni architekci.

Pośród szerokiej panoramy sposobów wykorzystywania odniesień do kultur regionalnych najbardziej nowatorskie miejsce zajmują awangardowi architekci łączący współczesną technologię, częste sympatie do ruchu nowoczesnego i nieoczywiste sposoby dialogu z historią. Nie charakteryzują się one jednorodną formą, obserwować można zróżnicowane strategie projektowe, co czyni architekturę współczesną architekturę inspirowaną kulturami lokalnymi żywą i zmienną, twórczo reagująca na postawione problemy projektowe.

Próbując dokonać systematyki współczesnych awangardowych sposobów odnoszenia się do tradycji regionalnej w pierwszych dwóch dziesięcioleciach XXI w., w opinii autora wyróżnić można trzy podstawowe strategie projektowe:

a) inspiracje formą architektoniczną;

b) inspiracje materiałem budowlanym i rzemiosłem;

c) inspiracje „ideą wspólnotową".

Ze względu na ograniczone możliwości ilości analizowanych przykładów, do szczegółowego omówienia przy- gionalism' which was supposed to be an alternative to universal modernist principles. Its creators established the following systematization of references to traditional architecture: "Let us take a chance and venture (...) that there are three major applications of partial use of the classical canon: (1) Citationism of classical motifs, or so-called freewheeling classicism; (2) syncretism; and (3) the use of classical fragments in architectural metastatement" (Jencks, Kropf, 2013, p. 219). The term 'critical regionalism' was creatively developed by local architects all over the world in the following years, diverging more and more from classical tradition and moving towards a greater application of local forms.

From the modern-day perspective, the emergence of postmodern theories in architectural design was the beginning of traditionalism revival. Its two main streams have persisted ever since: references to classical tradition, which best represents the ideas of 'new urbanism' promoted by Leon Krier and Prince Charles of Wales, as well as to 'critical regionalism', which systematically broadened its inspirations by architecture beyond classical tradition.

Inspirations with local culture in avant-garde architecture at the beginning of the 21st century

When trying to summarize the character of architecture inspired by local culture in the first two decades of the 21 st century, we have to pay attention to the multifaceted tendencies of the contemporary trends. 'Regionalism' became fashionable in various architectural conventions which evoked tradition in diverse ways. Consequently, its examples, often extremely dissimilar, are overabundant. They partly derive from traditional architecture attempting to implement original materials, techniques and forms in contemporary design. At the same time, other designs approach traditional influences superficially, using traditional forms as architectural details deprived of a connection to the structure and form of a building. Additionally, this diversity results from the fact that the contemporaneous architects draw from a multitude of traditions.

Among a wide range of references to regional cultures, the most innovative approach is represented by avant-garde architects who combine contemporary technologies, modern inclinations, and unobvious manners of evoking history. Their design projects are not uniform, they employ diverse strategies, which renders the contemporary architecture inspired by local cultures particularly vivid and versatile, seeking creative solutions to design problems.

The contemporary avant-garde references to regional traditions can be categorized into three elemental design strategies:

a) Inspirations with architectural form;

b) Inspirations with construction material and crafts;

c) Inspirations with the 'idea of community'.

On account of limited space for the analysis of specific examples, only three characteristic instances of each design strategy will be discussed in detail. 
jęto po trzy charakterystyczne przykłady dla każdej ze strategii projektowej.

\section{a) Inspiracje formą architektoniczną.}

Odnoszenie się do tradycyjnych form architektonicznych i ich transponowanie do współczesnych rozwiązań, pozostaje wciąż jedną z głównych dróg odwoływania się do architektury lokalnej. W architekturze nowego modernizmu i high-tech nawiązania te pojawiły się już w latach 80. i 90. XX w. Szeroko znanymi przykładami był m.in. Instytut Świata Arabskiego ${ }^{5}$ (1981-1987) autorstwa Jeana Nouvela, oraz Centrum Kulturalne Jean-Marie Tjibaou6 (1991-1998) autorstwa Renzo Piano. Nurt ten w XXI w. uległ dalszemu rozwojowi, przynosząc poza dotychczas znanymi sposobami odniesień, także nowe, wcześniej nieznane tendencje.

Jedną z najgłośniejszych obecnie realizacji urbanistycznych jest projekt miasta Masdar na pustyni pod Abu Dhabi. Powstające miasto, które w swych założeniach ma być samowystarczalne energetycznie, przewidziano w nim także m.in. wielkokrotne uzdatnianie wody, redukcję odpadów, które mają być zamieniane na energię, oraz wychwytywanie i składowanie dwutlenku węgla, uznać można za próbę realizacji architektonicznej utopii miasta przyszłości. Układ urbanistyczny zaprojektowany zostało przez pracownie Normana Fostera, a poszczególne budynki odnoszą się w swej formie w przeważającej części do estetyki architektury technologicznej. Jednak i w tak nowoczesnym środowisku pojawiły się odniesienia do tradycyjnej architektury arabskiej. Przykładem takiego sposobu projektowania może być Masdar Instytut (2010), który zaprojektowany został także przez pracownię Normana Fostera. W kompleksie tym znajduje się fragment zespołu mieszkaniowego. Jak piszą twórcy: „Okna w budynkach mieszkalnych są chronione przez współczesną reinterpretację maszrabijji, tradycyjnego arabskiego kratowego okna wykuszowego, zbudowanego z betonu, zabarwionego lokalnym piaskiem, aby zintegrować go z pustynnym kontekstem i zminimalizować konserwację. Rozwiązania sposobu doświetlenia i zacienienia oparte zostały na wzorach zaczerpniętych $z$ tradycyjnej architekturze islamu"7. Realizacja ta może być wymownym przykładem współczesnej implementacji detalu tradycyjnej architektury arabskiej.

Odmiennym przykładem wykorzystania inspiracji architekturą tradycyjną, jest projekt Hotelu Inntel (2010) w holenderskim mieście Zaandam autorstwa WAM Architecten. Hotel powstał w odnowionym centrum miasta, a jego inspiracją stały się charakterystyczne zielone domy, występujące w rejonie Zaan. Elewacja 11-piętrowego budynku jest swego rodzaju kolażem różnych przykładów tradycyjnych domów z regionu, od rezydencji notariusza po chaty robotnicze. Projekt ten proponuje zupełnie odmienny sposób komponowania elewacji, która sprawie wrażenie architektonicznego żartu, ocierającego się wręcz o formalny kicz. Dla zdefiniowania swojej metody projektowej autor Wilfried van Winden używa pojęcia "Fusion". Tak oto rozumie on ten sposób projektowania: "Fusion stanowi nowatorski sposób tączenia teraźniejszości i przeszłości, tradycji i innowacji, kultury wysokiej i niskiej. Generuje to nowatorską ekspresję, która odpowiada określonym lokalnym praktykom, ale

\section{a) Inspirations with architectural form}

References to traditional architectural forms and their transposition to contemporary design are one of the most important manners of evoking local architecture. In neomodern architecture and high-tech, such designs already emerged in the 1980s and '90s. Their well-known examples include the Arab World Institute $^{5}$ (1981-1987) designed by Jean Nouvel and JeanMarie Tjibaou Cultural Centre ${ }^{6}$ (1991-1998) designed by Renzo Piano. This movement further developed in the 21 st century, introducing new unknown trends to the commonly used modes of reference.

In recent years, one of the most famous urban projects is Masdar City located in the desert near Abu Dhabi. The city is intended to be self-sustainable, relying on renewable energy sources and equipped with a multiple water-purification system, a system recycling waste into energy, as well as a carbon dioxide storage and removal system. The project attempts to realize an architectural utopian vision of a futuristic city. Its urban plan was designed by the office of Norman Foster. Most of the buildings evoke the aesthetics of technological architecture. But despite the modern design environment, the project includes references to traditional Arabic architecture, the best example of which is the Masdar Institute (2010) also designed by the office of Norman Foster. The complex includes a residential unit described by its creators in the following way: "Windows in the residential buildings are protected by a contemporary reinterpretation of mashrabiya, a type of latticed projecting oriel window, constructed with sustainably developed, glass-reinforced concrete, coloured with local sand to integrate with its desert context and to minimize maintenance. The perforations for light and shade are based on the patterns found in the traditional architecture of Islam."7 This realization is a meaningful example of contemporary application of details derived from traditional Arabic architecture. A different example of inspiration with traditional architecture is a project of Inntel Hotel (2010) designed by WAM Architecten and located in the Dutch city of Zaandam. The hotel was built in the renovated city center and was inspired by green farmhouses characteristic of the Zaan region. The façade of this 11 -story building is composed of references to various traditional houses found in the area, such as notary's residence and workers' cottages. This project proposes an entirely different façade design, ${ }^{8}$ which appears to be an architectural joke verging on formal kitsch. In order to define his design method, its author Wilfried van Winden uses the term 'fusion'. $\mathrm{He}$ explains this method in the following way: "Fusion represents an inventive way of linking present and past, tradition and innovation, high culture and low. This generates a novel expressiveness that corresponds to specific local practices but is at the same time universal." 9 The project is especially noteworthy for its combination of high and low culture, as well as a reference to emotions as an architectural category. 


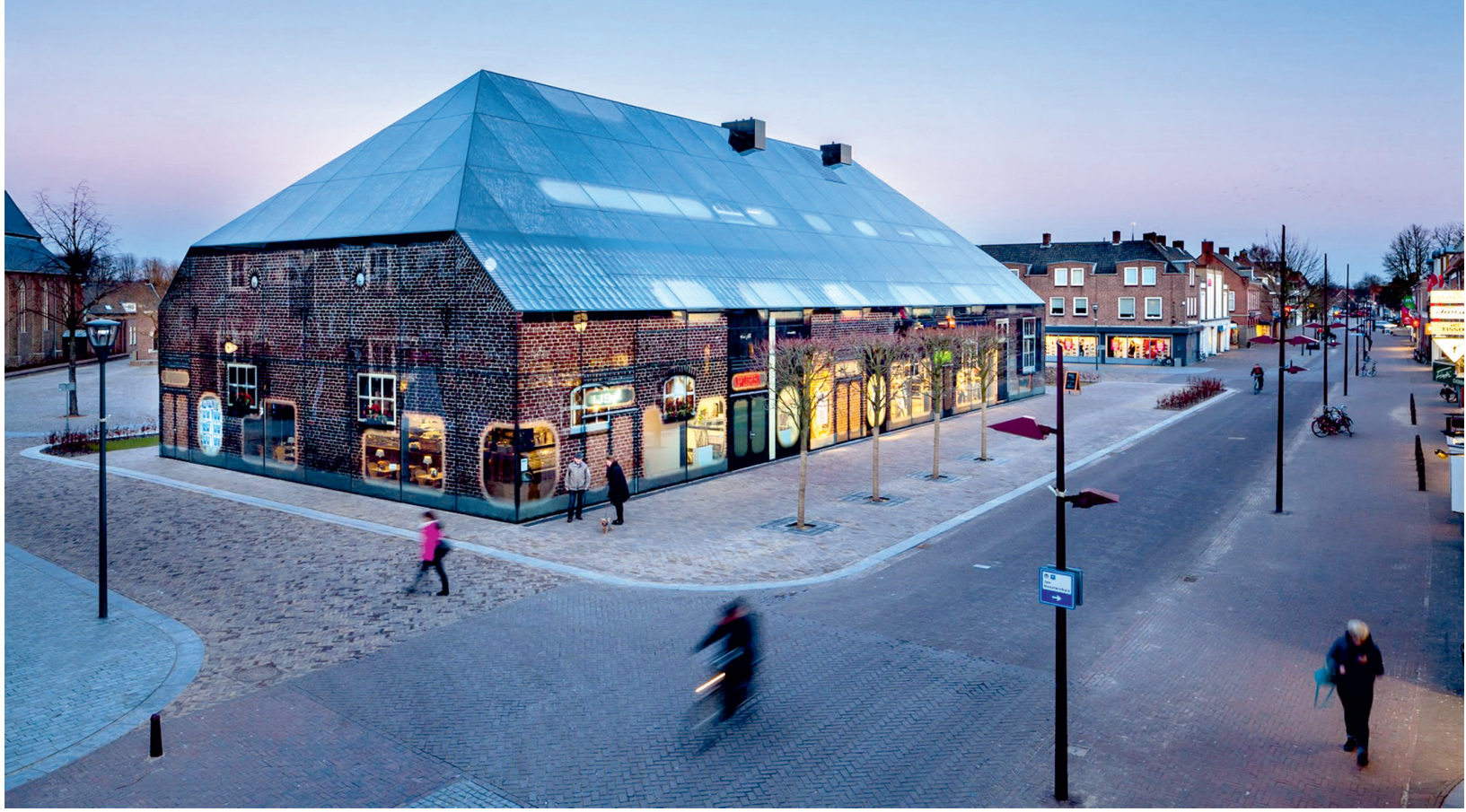

II. 2. Szklana farma (Glass farm) w Schijndel (Holandia) autorstwa MVRDV (2013). (Źródło: strona internetowa MVRDV.nl, https://www.mvrdv.nl/ projects/119/glass-farm, dostęp: 15.02.2020

III. 2. Glass Farm in Schijndel (Netherlands) designed by MVRDV (2013). (Source: https://www.mvrdv.nl/projects/119/glass-farm, accessed on 15 February 2020)

jednocześnie jest uniwersalna. Architektura w sposób naturalny odwołuje się do emocji"9. Na uwagę zasługują tu próby łączenia kultury wysokiej i niskiej, oraz odwołanie się do emocji, jako kategorii przynależnej architekturze.

Do pionierów wykorzystywania uproszczonej formy budynku parterowego z wysokim dachem należy holenderska grupa MVRDV. Pośród projektów odwołujących się do tego archetypu wymienić można: osiedle domów w haskiej dzielnicy Ypenburg (2005), czy też zlokalizowany na angielskiej prowincji w Suffolk projekt Balancing Barn (2010). W 2013 r. doszło do realizacji „Szklanej farmy" (il. 2.). Architekci w taki sposób opisują swój projekt: "Rynek Schijndela bardzo ucierpiał w wyniku bombardowań podczas II wojny światowe. Szklana Stodoła jest siódmą propozycją MVRDV dla tego miejsca (...). We wspótpracy z artystą Frankiem van der Salmem sfotografowano wszystkie pozostałe tradycyjne gospodarstwa w okolicy i opracowano "typową stodołe". Ten obraz został wydrukowany na szklane powłoce, która tworzy całą fasade. Szklana farma jest powiększona 1,6 razy, aby stworzyć pomnik tradycyjnego budynku"10. Bez wątpienia projekt ten uznać należy za przełamujący bariery technologiczne. Na uwagę zasługuje perfekcja wykonania szklanej powłoki, na której od strony zewnętrznej brak jest praktycznie elementów konstrukcyjnych, co czyni budynek rodzajem architektonicznej iluzji. Nowotarskim w rozwiązaniu jest sposób użycia lokalnego detalu architektonicznego, który został sfotografowany, a następnie powiększony, co czyni z projektu element rewitalizacji miasteczka, a także edukacji, służącej upamiętnieniu lokalnej architektury.

\section{b) Inspiracje materiałem budowlanym i rzemiosłem.}

Lokalne rzemiosło i związany z nim często charakterystyczne materiały budowalne (drewno, kamień, ceramika budowlana i inne), postrzegane były od końca XIX
The Dutch group MVRDV are pioneers of applying a simplified form of one-story building with a rake roof. Their projects evoking this type of building include a housing estate of Ypenburg in the Hague (2005) and the Balancing Barn (2010) built in the English countryside in Suffolk. In 2013, the company realized a project called Glass Farm (ill. 2.), described by its creators in the following way: "Schijndel's market square suffered badly from WWII bombing; the Glass Barn is MVRDV's seventh proposal for the site. (...) In collaboration with artist Frank van der Salm all the remaining traditional farms in the area were photographed and a 'typical farm' developed. This image was printed onto the glass envelope that forms the entire façade. The Glass Farm is scaled 1.6 times larger to create a monument to the traditional building."10 Beyond any doubt, this project breaks many technological constrictions. The perfect execution of glass shell, external side of which lacks any visible constructional elements, grants the building a look of an architectural illusion. Also, the local architectural detail has been implemented in an innovative way-its model was photographed and then enlarged, which not only serves as means of the town's revitalization but also pays tribute to the local architecture.

b) Inspirations with construction material and crafts Local crafts and their characteristic construction materials (wood, stone, building ceramics and others) were perceived as part of regional identity until the end of the 19th century. Their use was restricted to specific geographic areas, which granted them a unique formal character. An interesting phenomenon (occurring predominantly in poorer regions) that emerged in the 20th century was the processing of 
w. jako element identyfikacji regionalnej. Rozwiązania te były typowe dla mniejszych obszarów geograficznych i dzięki temu posiadały bardziej wyrazista specyfikę formalną. Interesującym zjawiskiem, szczególnie w mniej zamożnych rejonach, stało się w XX w. przetwarzanie lokalnego rzemiosła, które łączono z nowymi materiałami budowlanymi. Obecnie trendy te są kontynuowane.

Przykładem twórczej interpretacji tradycji architektury podhalańskiej, powstałej jeszcze przed pojawieniem się „stylu zakopiańskiego", są Pawilony Obsługi Ruchu Turystycznego (2018) w Tatrzańskim Parku Narodowym w Zakopanym. Projekt biura 2pm architekci wygrał ogólnopolski konkurs. Ta kameralna, licząca zaledwie $31 \mathrm{~m}$ kw. realizacja, składa się z dwóch pawilonów, stanowiących wejście do Tatrzańskiego Parku Narodowego. "Autorzy pawilonu wejściowego do Doliny Strążyskiej inspirowali się naturą, a skalą i materiałem nawiązali do dawnych szałasów i spichlerzy sytuowanych u wylotu dróg na skraju lasu. Nowa forma swą surowością koresponduje z dawnym budownictwem góralskim, sprzed stylu zakopiańskiego, a barwą i kształtem prowadzi dialog z przyrodą ${ }^{11}$.

W przypadku tej realizacji na uwagę zasługuje bardzo współczesna, minimalistyczne forma architektoniczna, która odnosi się jednak w sposób bezpośredni do lokalnych form i materiałów budowlanych.

We współczesnej architekturze wiele jest spektakularnych przykładów nawiązań do lokalnej tradycji, które zrealizowano w oparciu o wysokie budżety. W tym kontekście na uwagę zasługują realizacje skromniejsze, które poza odniesieniami kulturowymi, miały także wkład w aktywizację lokalnego środowiska. Modelowym przykładem takiego sposobu tworzenia architektury może być Francis Kéré. Ten architekt urodzony w Burkina Faso, jest absolwentem Politechnik Berlińskiej. Zasłynął on w 2001 r. realizacją szkoły w miejscowości Gando w Burkina Faso (il. 3.). Idea projektu stało się odrzucenie technologii żelbetowej i zrealizowanie nowego budynku z bloczków wytwarzanych z lokalnego mułu. Technologia taka była ryzykowna i kwestionowana przez lokalną local crafts and combining it with new building materials. This trend is still continued.

An example of a creative interpretation of architectural traditions of Podhale from before the onset of 'Zakopane Style' are two pavilions erected at the entrance to Tatra National Park (2018). The project designed by the studio ' $2 \mathrm{pm}$ architekci' won a national competition. This small-scale (31 sq. $\mathrm{m}$ large) realization consists of two pavilions serving as an entrance to Tatra National Park. "The authors of the entrance pavilions in the Strążyska Valley were inspired by nature, while in terms of scale and material, they referred to old huts and granaries located on roadsides at the edge of forest. By means of its austerity, this new form corresponds to the old mountain architecture predating the 'Zakopane Style', while its form and color refers to nature." 11 This realization is noteworthy for its contemporary, minimal architectural form which markedly evokes local forms and building materials.

Contemporary architecture abounds in spectacular instances of references to local tradition implemented in expensive projects. Nonetheless, more modest designs, which apart from cultural references also contributed to the activation of a local community, are equally significant. A model example of such a design are the works of Francis Kéré. This architect was born in Burkina Faso and graduated from the Technical University of Berlin. In 2001, he gained international recognition for a project of the Gando Primary School in Burkina Faso (ill. 3.). In this project, Kéré renounced reinforced concrete technology and replaced it with locally made mud bricks. The new technology was risky and raised concerns of the local population worried that mud brick construction would not survive the rain season. Kéré, however, found a solution to this problem by providing his structure with a wide, raised tin roof which protected the walls from the rain. The architect involved the

II. 3. Szkoła Gando w Burkina Faso autorstwa Kéré Architecture (2001). (Źródło: strona internetowa www.dezeen.com, https://www.dezeen. com/2017/10/17/movie-diebedo-francis-kere-gando-school-burkina-faso-interview-video/, dostęp: 15.02.2020)

III. 3. Gando Primary School in Burkina Faso created by Kéré Architecture (2001). (Source: https://www.dezeen.com/2017/10/17/movie-diebedo-francis-kere-gando-school-burkina-faso-interview-video/, accessed on 15 February 2020)

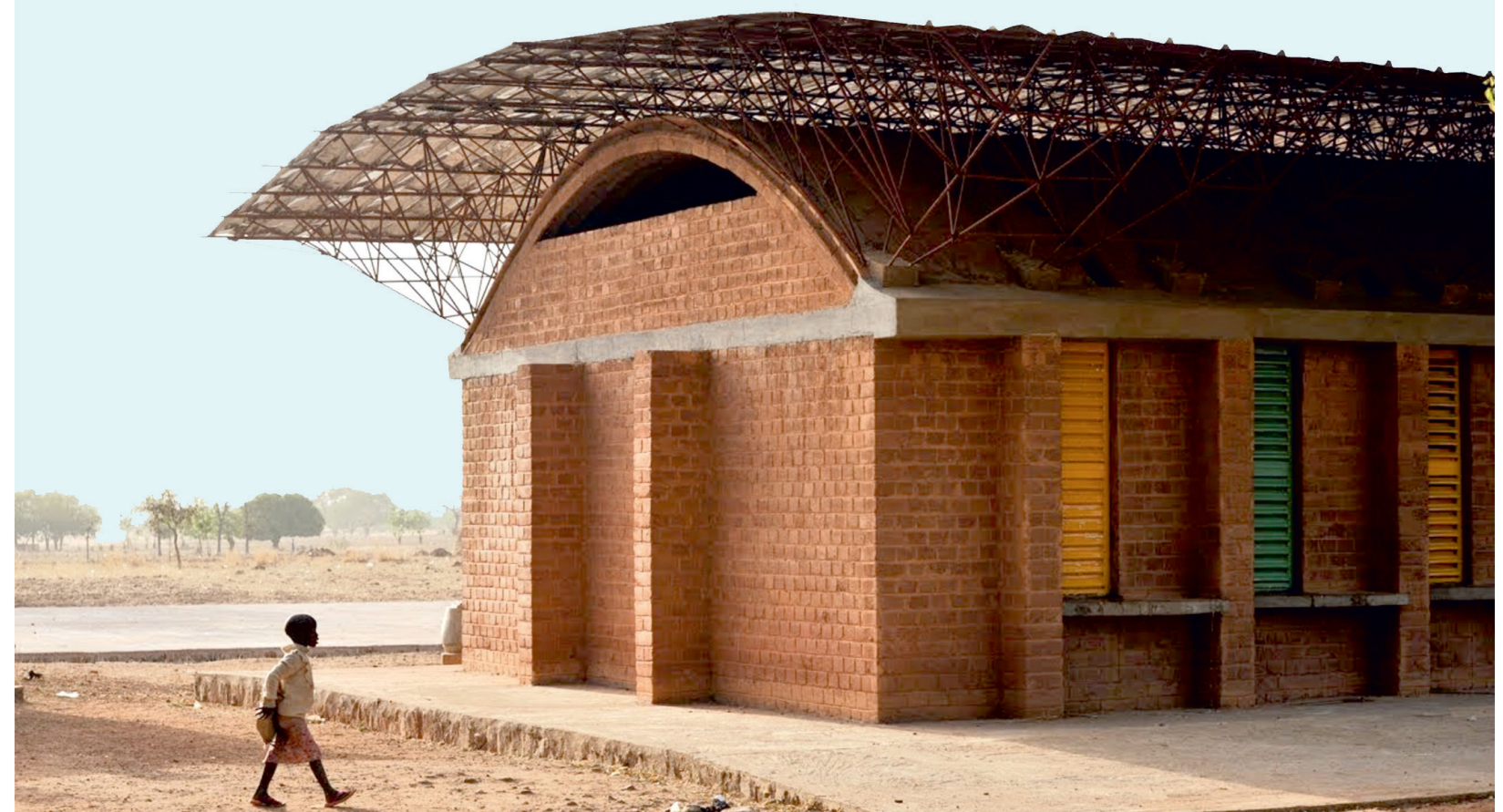


społeczność, ponieważ obawiano się zniszczenia bloczków w czasie pory deszczowej. W związku z tym Kéré zaproponował stworzenie rozłożystego dachu, który chroni zarówno przed deszczem jak i słońcem. Przy realizacji projektu architekt zaangażował mieszkańców wioski. Realizacja szkoły stała się impulsem rozwojowym, przyciągnęła do niej nowych mieszkańców i zgodnie z zasadą „śnieżnej kuli”, przyczyniła się do nowych realizacji. W wiosce powstały inne projekty Kéré: biblioteka szkolna, domy dla nauczycieli, oaza, szkoła średnia, oraz dom kultury. Wszystkie te budynki oparto o wypracowaną technologię użycia lokalnego mułu, która łączona jest z żelbetowymi elementami konstrukcyjnymi, oraz charakterystycznymi, przestrzennymi konstrukcjami dachu. Jeszcze innym przykładem odniesień do lokalnego rzemiosła i wykorzystania historycznych materiałów budowlanych, reprezentuje twórczość chińskiego architekta Wang Shu. Jego postawa twórcza kontestuje ekspansywny model urbanizacji Chin z początków XXI w., który oparty jest na w znacznej części na imporcie zachodniej myśli architektonicznej i odrzuceniu tradycyjnej architektury chińskiej. Dynamika tych przemian powoduje, że część historycznej architektury znajduje się w sposób dosłowny na „śmietniku historii". Rozbierane są zespoły i zabytki, które posiadają wielowiekowy rodowód. Wang Shu postanowił inkorporować te elementy i poddawać je architektonicznemu recyklingowi. Głównymi materiałami budowlanymi, które są przez niego ponownie wykorzystywane są porozbiórkowe cegły i dachówki. Najbardziej spektakularnym przykładem takiej realizacji jest Muzeum Historii w Ningbo (2003-2008). Powstało ono na terenach dawnego portu i było elementem rewitalizacji dzielnicy. Architekt wkomponował w bryłę budynku dawną poczekalnię. Zaangażował on do pracy lokalnych murarzy, którzy pod jego nadzorem budowali nowe ściany, używając częściowo historycznego materiału. Propozycje Wang Shu pozostają w opozycji wobec powierzchownych interpretacji chińskiej tradycji i nadawaniu nowoczesnym budynkom odniesień do form pagody. Kładzie on nacisk na powierzchnie i detal, jako istotne elementy wielowiekowej chińskiej tradycji. Ułożenie resztek materiałów budowalnych traktować można jako rodzaj „architektonicznej archeologii", odwołującej się bezpośrednio do konstrukcji murów tworzonych przez wieki przeciw tajfunom. Należy także podkreślić, że sam układ przestrzenny, w tym m.in. centralny dziedziniec, oraz drewniane mostki, łączące różne części Muzeum, nawiązują do lokalnych rozwiązań architektonicznych.

\section{c) Inspiracje „ideą wspólnotową"}

Inspiracje formą architektoniczną, materiałem budowlanym i rzemiosłem, choć osiągnęły współcześnie bardzo znaczący poziom transformacji, to jednak odnoszą się do materialnego dziedzictwa. W dwóch pierwszych dziesięcioleciach XXI w. pojawiła się także nowa tendencja, którą zdefiniować można jako - inspiracje „ideą wspólnotową". Istotą tego sposobu projektowania jest wyabstrahowanie cech charakterystycznych dla danej społeczności, środowiska kulturowego, lub środowiska naturalnego i nadanie im nowatorskiej formy architektonicznej. Często rozwiązania te są rodzajem „architektonicznej gry" ze zróżnicowanymi poziomami kodów kulturowych. Istotną ich cechą bywa ironia, która nadaje tym realizacją świeżości i formalnej atrakcyjność. Ten typ projektowania najpełniej widoczny jest w projektach pawilonów narodowych tworzonych na potrzeby wystaw światowych entire local community in the construction of the school, which proved to be an incentive for further development of the village. The project attracted new inhabitants and led to subsequent realizations of Kéré's projects: a school library, teachers' housing, garden and well, secondary school and community center. All of these structures were erected by means of the technology that combined the use of local mud bricks with reinforced concrete construction components covered by characteristic spatial roof structures.

Another example of references to local crafts combined with the use of historical building material are works of Wang Shu, a Chinese architect. His creative approach challenges the expansionary model of Chinese urbanization dominant at the beginning of the 21st century, which largely rested upon Western architectural conceptions, discarding traditional Chinese architecture. The dynamic changes in Chinese urban areas consign significant parts of historical architecture to the 'dustbin of history'. Many centuries-old historical complexes and monuments are being torn down. Wang Shu decided to save some parts of this heritage by incorporating its components in his projects and subjecting them to the process of architectural recycling. The building material he especially favors are recycled post-demolition bricks and roof tiles. The most spectacular example of such a solution is the Ningbo Historic Museum (2003-2008). It was built in an old port as part of a district revitalization project. The architect incorporated an old waiting room into the building structure. He engaged local bricklayers in construction works, who built new walls under his supervision, partly using historical material. Wang Shu's designs oppose superficial interpretations of Chinese tradition, which usually refer to the form of pagoda, while they foreground the surface and details as important components of long-lived Chinese tradition. Compositions made of building material residues may be seen as a sort of 'architectural archeology', directly drawing on walls customarily constructed as protection against typhoons. Additionally, the spatial arrangement including the central courtyard and wooden bridges linking various parts of the museum refer to local architectural patterns.

\section{c) Inspirations with the 'idea of community'}

Even though the inspirations with architectural form, building material and crafts have presently achieved a high level of transformation, they are still based upon material heritage. In the first two decades of the 21st century, there emerged a tendency which can be best defined as inspiration with the 'idea of community'. This method of design isolates characteristic features of a specific community or cultural environment and combines them with an innovative architectural form. Such designs are frequently a sort of an 'architectural game' involving different levels of cultural codes. 


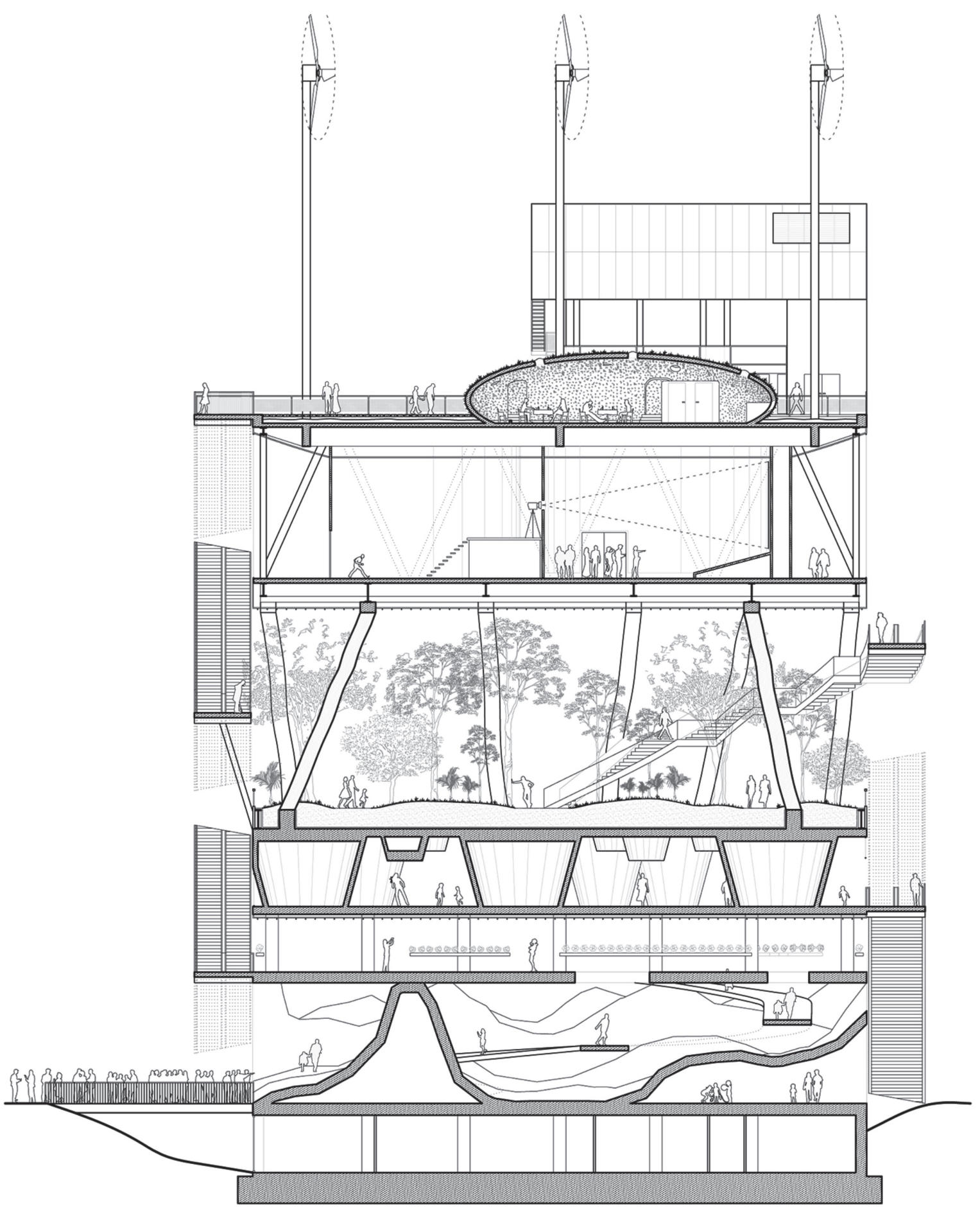

II. 4. Przekrój ideowy przez Pawilon Holenderski na wystawę EXPO w Hanowerze w 2000 r. autorstwa MVRDV. (Źródło: Strona internetowa MVRDV.nl (https://www.mvrdv.nl/projects/158/expo-2000, dostęp: 15.02.2020)

III. 4. Cross-section of the Netherlands Pavilion at 2000 World EXPO in Hannover, designed by MVRDV. (Source: https://www.mvrdv.nl/projects/158/ expo-2000, accessed on 15 February 2020)

EXPO. Specyfika tych wystaw wymusza wręcz na projektantach konieczność poszukiwania rozwiązań, które wyróżnią się na tle innych pawilonów. W dłuższej perspektywie prowadzito to do odchodzenia w projektowaniu najbardziej awangardowych pawilonów narodowych od form i materiałów charakterystycznych dla danego kraju, na rzecz architektonicznych prób wyrażenia idei, które te kraje chciałyby symbolizować.
They also employ irony in a characteristic way, which grants them the quality of freshness and formal attractiveness. This design method is most often used in the projects of national pavilions at World's fairs popularly known as EXPO. The character of the fair utterly compels the creators to propose outstanding solutions which will distinguish their projects from other pavilions. Consequently, in the case of the most 
Jako przełomowy w tym zakresie uznać można PawiIon Holenderski (il. 4.) na wystawę EXPO w Hanowerze (2000). Ideą pawilonu autorstwa grupy MVRDV stało się stworzenie przestrzeni, która byłaby podróżą przez krajobrazy Holandii. W żelbetowej otwartej strukturze architekci wytyczyli ścieżkę, po której mieli podążać zwiedzający, zderzając ich z artefaktami, które miały przypominać „typowy krajobraz holenderski”. Jak piszą o swoim dziele sami twórcy: "Architektura sugeruje holenderską otwartość, odwołując się równocześnie do stereotypów związanych z holenderskim krajobrazem: tulipanów, wiatraków i wodnych śluz. (...) Pawilon (...) stawiał pytania o rodzaj "nowego środowiska", mieszanki technologii i natury, podkreślają zdolność do tworzenia i sztuczności"12. Na podkreślenie zasługuje tu ironia, ocierająca się wręcz o kicz (tulipany, wiatraki), która łączy się równocześnie z przekonaniem, że krajobraz przyszłości będzie efektem połączenia środowiska kulturowego i naturalnego.

Podobną strategię projektową prezentował Pawilon Duński zaprojektowany przez BIG, ARUP i 2+1 na Shanghai EXPO 2010. W ogólnym założeniu pawilon ten był pętlą, po której zwiedzający jeździli jednym z 1500 rowerów dostępnych przy wejściu. „W centrum pawilonu zaprojektowano basen ze słodką wodą z portu w Kopenhadze (jednym z najczystszych na świecie). (...) Na środku basenu znalazła się Mała Syrenka, posąg będący symbolem Danii. (...). Jak powiedział Bjarke Ingels: "przeniesienie Małej Syrenki do Chin jest znacznie bardziej oszczędne niż przeniesienie 1,3 miliarda Chińczyków do Kopenhagi"13. Projekt uznać można za próbę „wyrażenia ducha Danii", która w formie ironicznej, zinterpretowana została jako „ścieżka rowerowa". Bjarke Ingels w taki oto sposób podsumował swój projekt: „W Pawilonie Duńskim próbowaliśmy skonsolidować doświadczenia, w jaki sposób zrównoważone miasto - takie jak Kopenhaga - może podnieść jakość życia"14.

Trzecim przykładem odniesień do „tradycji wspólnotowej" może być Pawilon Brytyjski na Milan EXPO 2015. Idea pawilonu, którą stworzył artysta Wolfgang Buttress i inżynier Tristan Simmondsen, oparta została na odniesieniu do gigantycznego ula stojącego pośród łąki porośniętej dzikimi kwiatami. „Odwiedzający pawilon podążają za tańcem pszczoły, podróżując przez szereg krajobrazów. Doświadczenie rozpoczyna się od podróży przez sad, polną łąke z dzikimi kwiatami, a następnie do imponującego centrum: ula, rzeźbionego elementu o średnicy 14 metrów, wykorzystującego światło i dźwięk do symulacji odczuć prawdziwego ula15". Odniesienie do ula i pszczół, należy w przyjętym rozwiązaniu interpretować w sposób symboliczny, odnoszący się do tradycji i teraźniejszości Imperium Brytyjskiego, które „roznosi” („zapyla”) idee na cały świat. Także i w tym przypadku można mówić o wielopoziomowym konotowaniu znaczenia przekazu architektonicznego, oraz ironii.

\section{Podsumowanie wyników badań}

Podsumowując przeprowadzone badania dotyczące wpływu inspiracji tradycji lokalnych na rozwiązania awangardowych nurtów w architekturze pierwszych dwóch dziesięcioleci XXI w., należy podkreślić, że wpisują się one w panoramę zróżnicowanych bodźców, avant-garde pavilions this results in the rejection of forms and materials characteristic of a specific country, in favor of attempts to express the ideas represented by this country by architectural means.

In this respect, the Netherlands Pavilion (ill. 4.) constructed for the 2000 World EXPO in Hannover was a breakthrough. The pavilion created by the MVRDV group was conceived as a space providing an opportunity to take a journey through Dutch landscapes. In an open reinforced-concrete structure, the architects placed a path for the visitors who encountered various attributes reminiscent of a 'typical Dutch landscape'. The creators described their work in the following way: "The architecture suggests Dutch open-mindedness whilst referencing stereotypes associated with the Dutch landscape: tulips, windmills and dykes. (...) The Netherlands Pavilion at the 2000 World Expo sought to reflect on this 'new nature': a mix of technology and the natural, emphasizing nature's make-ability and artificiality." 12 The irony verging on kitsch (tulips, windmills) derives here from a conviction that the landscape of the future will be a combination of cultural and natural environment. A similar design strategy was adopted in the project of the Denmark Pavilion at the 2010 World EXPO in Shanghai, designed by BIG, ARUP and $2+1$. It housed a loop on which visitors rode around on one of 1,500 bicycles available at the entrance. "At the center of the pool you will find The Little Mermaid, a statue that has become a symbol for Denmark. And this time, it will be moved temporarily to China. In Bjarke Ingels words 'it is considerably more resource efficient moving The Little Mermaid to China, than moving 1.3 billion Chinese to Copenhagen'". ${ }^{13}$ The project may be seen as an attempt to express the 'spirit of Denmark', which was ironically envisioned as a bike path. Bjarke Ingels commented on his project in the following way: "With the Danish Pavilion we have attempted to consolidate a handful of real experiences of how a sustainable city-such as Copenhagen-can in fact increase the quality of life."14 The third example of references to 'community tradition' is the UK Pavilion created for the 2015 World EXPO in Milan. Its designers, artist Wolfgang Buttress and engineer Tristan Simmondsen, envisaged the building as a gigantic beehive located in the middle of a wildflower meadow. "Visitors to the Pavilion follow the dance of a bee, travelling through a series of landscapes. The experience starts with a journey through an orchard, followed by a wildflower meadow and on to an impressive centerpiece: The Hive, a $14 \mathrm{~m}$-cubed sculptural element that uses light and sound to simulate the activity of a real beehive."15 The reference to a beehive and bees may be interpreted in a symbolic manner as drawing on the tradition and presence of the British Empire which disseminates its ideas all over the world in an act parallel to pollination. As in the case of previous examples, this design conveys a multilevel architectural meaning and makes use of irony. 
wpływających na rozwój architektury współczesnej od końca XIX w. Tradycja lokalna, znajdując się w opozycji wobec poszukiwań głównych nurtów, stanowiła w różnych okresach ich alternatywę. Formy regionalne traktowano najczęściej jako symbole, celowo odcinające się od uniwersalności przekazu architektonicznego i podkreślające wspólnotowość architektury. Wspólnotowość ta w różnych okresach definiowana była w zróżnicowanych zbiorach. W perspektywie historycznej sięgającej od drugiej połowy XIX w. do końca XX w. według autora, wyróżnić można cztery podstawowe nurty: a) „neohistoryczne style narodowe”; b) „fascynację architekturą swojską"; c) regionalizmu w architekturze modernizmu; oraz d) postmodernistycznej restytucji regionalizmu. Każdy z tych nurtów miał pośredni, lub bezpośredni wpływ na współczesną twórczość.

Mimo kontynuacji, architektura inspirowana kulturami lokalnymi powstająca w dwóch dziesięcioleci XXI w. posiada oryginalną formę, odróżniającą ją od doświadczeń wcześniejszych. Według autora do najważniejszych jej oryginalnych cech należy zaliczyć:

- porzucenie poszukiwań „stylu narodowego” na rzecz „cech wspólnoty";

- kontynuowanie poddanych restytucji w okresie postmodernizmu odniesień do tradycji architektury porządkowej;

- dynamiczny rozwój kierunków odwołujących się do specyfiki mniejszych regionów i ich tradycji budowlanych (tradycji architektonicznych „małych ojczyzn”);

- nowatorskie wykorzystywanie lokalnych tradycji rzemieślniczych i materiałów, które bywają łączone z nowymi materiałami i technologiami;

- użycie technologii cyfrowych;

- wykorzystywanie realizacji opartych o lokalną tradycję do programów aktywizacji społecznej;

- wprowadzenie ironii, a nawet kiczu, jako świadomych elementów odniesień kulturowych.

W opinii autora, w zglobalizowanej rzeczywistości współczesnej architektury, poszukiwania indywidualności, odnoszącej się do regionalnych tradycji, znajdować będzie w nieodległej przyszłości wielu twórczych kontynuatorów, a rodzaj tych odniesień stanie się coraz bardziej abstrakcyjny.

\section{PRZYPISY}

${ }^{1}$ W przypadku architektury fińskiej, a szczególnie twórczości Alvara Aalto, z perspektywy współczesnych poszukiwań inspiracji architekturą regionalną, jako ważne uznać należy: a) zastosowanie lokalnych rozwiązania materiałowe (drewno, oraz materiały drewnopochodne), b) twórcze wprowadzanie rozwiązań kompozycyjnych służących zwiększeniu dostẹpności promieni słonecznych (m.in. stosowanie doświetleń, oraz zwiększanie powierzchni nasłonecznionych ścian). Rozwiązania te przejęte zostały z czasem także przez innych twórców spoza Skandynawii, poszerzając formalistyke modernizmu.

${ }^{2}$ W przypadku architektury brazylijskiej jako najważniejsze uznać należy próbę wyrażenia „ducha narodu brazylijskiego" poprzez abstrakcyjne, krzywoliniowe formy. Punktem zwrotnym dla rozwoju modernistycznej architektury brazylijskiej okazał sie projekt Casa do Baile (1940) w Pampulha koło Belo Horizonte autorstwa Oscara Niemeyera. Jako pierwsza w duchu funkcjonalistycznego modernizmu zaprojektowana została restauracja, która przeznaczona była dla zamożnych klientów. Jako druga powstała sala taneczna, w której architekt wprowadził linii krzywą, która miała być architektoniczną ilustracją samby i szerzej - ekspresyjnej kultury Brazylii. ${ }_{3}$ Najbardziej wpływowym architektem japońskim w tym okresie pozostawał Kenzo Tango, w którego twórczości zauważyć można inspiracje architekturą tradycyjną. Jako przykłady tych wpływów podać można: dom własny (1951-1953), który architekt oparł na systemie mat tatami, oraz

\section{Summary of research results}

Summarizing the research conducted on the influence of inspirations drawn from local traditions on avant-garde trends in the architecture of the first two decades of the 21 st century, we have to note that it originates from a wide range of factors which have been shaping the development of modern architecture since the end of the 19th century. Resisting the mainstream development, local tradition served as its alternative in various periods. Regional forms were most frequently treated as symbols set apart from the universal meaning of architecture and used to emphasize a communal aspect of architectural design. This aspect was differently defined in various periods. From the historical perspective spanning the second half of the 19th century and the entire 20th century, four main trends can be distinguished: a) 'neo-historical national style', b) interest in 'homey architecture', c) regional traditions in modernist architecture, d) postmodern revival of regional traditions. Each of these trends had a direct or indirect influence on contemporary creations.

Despite its continuity, 21st-century architecture inspired by local cultures has original form, which distinguishes it from earlier design. According to the author of this article, its original features include:

- Rejection of the 'national style' in favor of 'community style';

- Continuation of postmodern restitution of references to classical order architecture;

- Dynamic development of trends inspired by regional character and architectural traditions (the so-called architectural small homelands);

- Innovative application of local building materials and crafts often combined with new materials and technologies;

- Involvement of local communities in realizations of projects inspired by local tradition;

- Introduction of irony verging on kitsch as a conscious reference to local cultures.

According to the author of this contribution, in the globalized reality of contemporary architecture, a search for individuality based on regional tradition will soon find numerous continuators, while the character of these references will become more and more abstract.

\section{ENDNOTES}

1 In the case of Finnish architecture, and especially the works of Alvar Aalto, features characteristic of inspirations with regional architecture include: a) implementation of local materials (wood, wood-based materials); b) a creative implementation of compositions intended to increase the penetration of sunlight (e.g. lighting solutions and the increase of lighted wall surface). These ideas were taken over by designers from outside of Scandinavia, which contributed to the spread of modernist formal features.

2 In the case of Brazilian architecture, the most significant inspiration by local culture was an attempt to express the 'spirit of the Brazilian nation' by means of abstract, curved forms. The turning point of the modernist architecture development in Brazil was Casa do Baile (1940) in Pampulha near Belo Horizonte designed by Oscar Niemeyer. Its restaurant was the first design that followed the principles of functional modernism. The architect introduced a curved line to the dancing room of the same building, which was intended to reflect the movements of samba and-more metaphoricallythe expressive spirit of Brazilian culture. 
kompleks olimpijski Yoyogi National Gymnasium (1964), w którym połączył europejską awangardę i tradycyjne formy japońskich przykryć dachowych.

${ }_{4}$ Zjawisko wpływu regionalizmu $\mathrm{w}$ architekturze modernistycznej miało znacznie szerszy oddziaływanie i jego przykłady znaleźć można w historii architektury wielu krajów. W architekturze polskiej jako jeden z najbardziej znaczących przykładów realizacji z tego obszaru można wskazać projekt Centralnego Ośrodka Sportów (1957-1960) w Zakopanem, który inspirowany krajobrazem Tatr, zaprojektowany został przez zespół architektów działających przy Politechnice Krakowskiej: Andrzeja Skoczka, Bogumiła Zaufala, Stanisława Karpiela.

${ }^{5} \mathrm{~W}$ budynku tym promującym kulture arabska zaprojektowano ruchome ornamenty elewacyjne, dozujące dostęp światła, które w swej formie transponowały dekoracyjne motywy architektury arabskiej.

${ }^{6}$ Budynek ten przypomina tradycyjne chaty z kaledońskiej wsi. Ponadto architekt w sposób świadomy nadał im formę niedokończonej budowli, co miało stanowić odniesienie do zmieniające się kultury Kanaków.

7 https://www.archdaily.com/91228/masdar-institute-foster-partners, dostęp 15.02.2020.

${ }^{8}$ W odróżnieniu od kompozycji elewacji układ funkcjonalny budynku został rozwiązany w sposób powtarzalny i typowy.

9 https://www.dezeen.com/2010/05/17/inntel-hotel-by-wam-architecten/, dostęp 15.02.2020

10 https://www.mvrdv.nl/projects/119/glass-farm, dostęp w dniu 15.02.2020

${ }^{11}$ (Forczek-Brataniec, 2019)

12 https://www.mvrdv.nl/projects/158/expo-2000, dostęp w dniu 15.02.2020.

13 https://www.archdaily.com/6465/denmark-pavillion-for-shangai-expo-2010-big, dostęp: 15.02.2020

14 https://www.archdaily.com/6465/denmark-pavillion-for-shangai-expo-2010-big, dostęp: 15.02.2020.

15 www.archdaily.com (https://www.archdaily.com/627728/uk-pavilion-milan-expo-2015-wolfgang-buttress, dostęp 15.02.2020.

\section{BIBLIOGRAFA}

[1] Chmielewski W.J., 2017, Regionalizm współczesnej architektury reakcja na procesy globalizacji, Kraków: Wydawnictwo Politechniki Krakowskiej.

[2] Fauria G., Evers B., Thoenes Ch.,2003, Architectural Theory From The Renaissance to The Present (2003), Köln: Taschen.

[3] Forczek-Brataniec U., 2019, Pawilony wejściowe do Tatrzańskiego Parku Narodowego, Architektura - Murator, https:// architektura.muratorplus.pl/realizacje/pawilony-wejsciowe-dotatrzanskiego-parku-narodowego 9333.html dostep 15.02.2020.

[4] Jencks Ch., Kropf K., 2013, Teorie i manifesty architektury wspótczesnej, Warszawa: Grupa Sztuka Architektury.

[5] Matuszewski K., 1880, Rzut oka na rozwój sztuki w ogólności, na jej dzieje i stan obecny u nas. Warszawa: Biblioteka Warszawska.

[6] Stefański K., 2002, Polska architektura sakralna w poszukiwaniu stylu narodowego, Łódź: Wydawnictwo Uniwersytetu Łódzkiego. [7] https://www.archdaily.com/627728/uk-pavilion-milan-expo2015-wolfgang-buttress, https://www.archdaily.com/6465/denmark-pavillion-for-shangai-expo-2010-big, dostęp 15.02.2020. [8] https://www.dezeen.com/2017/10/17/movie-diebedo-franciskere-gando-school-burkina-faso-interview-video, dostep 15.02.2020. [9] https://www.mvrdv.nl (https://www.mvrdv.nl/projects/158/ expo-2000, dostęp 15.02.2020. 10. https://www.mvrdv.nl/projects/119/glass-farm, dostęp 15.02.2020.
${ }^{3}$ The most influential Japanese architect in this period was Kenzo Tange, whose works display inspirations with traditional architecture. An example of these influences is Tange's own home (1951-1953) based on the traditional Japanese module made of the tatami mat, as well as Olympic arenas Yoyogi National Gymnasium (1964), which combines the European avant-garde with traditional forms of Japanese roof covers.

${ }^{4}$ The phenomenon of regional influences in modernist architecture had a significant impact on the history of architecture in many countries. In Polish architecture, its most remarkable example is the design of Centralny Ośrodek Sportów (1957-1960) in Zakopane, inspired by the landscape of the Tatra mountains. It was created by a team of architects related to the Technical University of Krakow: Andrzej Skoczek, Bogumił Zaufal and Stanisław Karpiel.

5 The façade of the Arab World Institute building is decorated with moveable shutters inspired by decorative motifs of Islamic architecture that control the amount of light and heat entering the building from the sun.

${ }^{6}$ This building resembles traditional cottages from the New Caledonian countryside. Additionally, the 'unfinished' look was intended to refer to the transforming culture of the Kanak people.

7 https://www.archdaily.com/91228/masdar-institute-foster-partners, accessed on 15 February 2020.

8 In contrast to the façade, the functional arrangement of the building is regular and typical.

9 https://www.dezeen.com/2010/05/17/inntel-hotel-by-wam-architecten/, accessed on 15 February 2020.

10 https://www.mvrdv.nl/projects/119/glass-farm, accessed on 15 February 2020.

${ }^{11}$ (Forczek-Brataniec, 2019)

12 https://www.mvrdv.nl/projects/158/expo-2000, accessed on 15 February 2020.

13 https://www.archdaily.com/6465/denmark-pavillion-for-shangai-expo-2010-big, accessed on 15 February 2020.

14 https://www.archdaily.com/6465/denmark-pavillion-for-shangai-expo-2010-big, accessed on 15 February 2020.

15 https://www.archdaily.com/627728/uk-pavilion-milan-expo-2015-wolfgang-buttress, accessed on 15 February 2020.

\section{REFERENCES}

[1] Chmielewski W.J., 2017, Regionalizm wspótczesnej architektury reakcja na procesy globalizacji, Kraków: Wydawnictwo Politechniki Krakowskiej.

[2] Fauria G., Evers B., Thoenes Ch.,2003, Architectural Theory From The Renaissance to The Present (2003), Köln: Taschen.

[3] Forczek-Brataniec U., 2019, Pawilony wejściowe do Tatrzańskiego Parku Narodowego, Architektura - Murator, https://architektura.muratorplus.pl/realizacje/pawilony-wejsciowe-do-tatrzanskiego-parku-narodowego 9333.html, dostep 15.02.2020.

[4] Jencks Ch., Kropf K., 2013, Teorie i manifesty architektury współczesnej, Warszawa: Grupa Sztuka Architektury.

[5] Matuszewski K., 1880, Rzut oka na rozwój sztuki w ogólności, na jej dzieje i stan obecny u nas, Warszawa: Biblioteka Warszawska.

[6] Stefański K., 2002, Polska architektura sakralna w poszukiwaniu stylu narodowego, Łódź: Wydawnictwo Uniwersytetu Łódzkiego.

[7] https://www.archdaily.com/627728/uk-pavilion-milan-expo-2015-wolfgang-buttress, https://www.archdaily.com/6465/denmark-pavillion-for-shangai-expo-2010-big, dostęp 15.02.2020.

[8] https://www.dezeen.com/2017/10/17/movie-diebedo-francis-kere-gando-school-burkina-faso-interview-video, dostepp 15.02.2020.

[9] https://www.mvrdv.nl (https://www.mvrdv.nl/projects/158/expo-2000, dostęp 15.02.2020.

[10] https://www.mvrdv.nl/projects/119/glass-farm, dostęp 15.02.2020. 